E-ISSN: 2808-5361 http://e-journal.fkmumj.ac.id/
Proceeding The First

Muhammadiyah Internasional-

Public Health and Medicine

Conference

\title{
Characteristics of Refill Drinking Water Depot and Bacteriology Evaluation in Covid-19 Period
}

\author{
${ }^{1}$ Herniwanti, ${ }^{2}$ Endang Purnawati Rahayu, ${ }^{3}$ Yen Purwawinata Mohan \\ ${ }^{1,2,3}$ Magister of Public Health, Institute of Health Sciences Hang Tuah Pekanbaru, Indonesia. \\ Pekanbaru Indonesia, Mustafa Sari Street Number.5, South Tengkerang., Bukit Raya, Pekanbaru, Riau 28281 \\ E-mail: herniwanti@htp.ac.id
}

\begin{abstract}
Accessing the characteristics of Refill Drinking Water Depot (DAMIU) is the initial step in mapping the quality of water to be processed into drinking water. Therefore, this study aims to map the characteristics and bacteriology of DAMIU raw water at the Koto Kampar Hulu sub-district to prevent COVID-19. This was a study conducted using a qualitative approach with 7 raw water samples. The bacteriology of Raw Water (E. Coli and Coliform) is an indicator of the required standards in line with the minister of health regulation No.32 of 2017. Furthermore, the results showed that $85 \%$ of the DAMIU raw water originated from drilling and dug wells. The distance to water sources was mostly $<20 \mathrm{~km}$. Bacteriological tests for E. Coli were consistent with the quality standards while 4 DAMIU sources contain Coliform bacteria due to poor hygiene. Hence, it is recommended that the health department, responsible for consumer protection and law enforcement, provide guidance and supervision to DAMIU entrepreneurs that failed to meet the requirements. Further PAMSIMAS, PHBS, and STMB programs as well as other technological innovations are needed to provide a drinking water source that is healthy, cheap, and protected from disease during the COVID-19 period.
\end{abstract}

Keywords: Drinking water, Bacteriology, Coliform, Covid-19 


\section{INTRODUCTION}

Raw water originates from natural sources such as mountain springs, rivers, drilling and dug wells, as well as rainwater. It functions as a source of drinking water for the community with or without processing. Meanwhile, the environmental health standards by the minister of health regulation no.32 of 2017 [1] aim to ensure that the water sources consumed by the community follow quality standards, especially bacteriology to prevent side effects [2]. The regulation also states that quality control of raw water needs to be carried out at least once a year by the local health office.

Refill Drinking Water Depot (DAMIU) is a community-based effort in managing drinking water in a bulk-filled system with an average capacity of 20 liters/gallon. Meanwhile, related DAMIU characteristics are measured in terms of depot conditions, source, as well as the distance from the raw water. This enables the environmental health officials at the community health center to monitor quality standards, especially the bacteriology of DAMIU as this potentially affects the health of the consumers. Research in Kupang City (2015) on 51 DAMIU reported that $51 \%$ were contaminated with Total Coliform and E. Coli bacteria due to improper sanitation [3]. Meanwhile, the microbiological quality standards for raw water based on the Ministry of Health Regulation, [4] recommended a Total coliform <50 CFU / $100 \mathrm{ml}$ and E. coli $0 \mathrm{CFU} / 100 \mathrm{ml}$. Generally, the physical parameters of raw water sources in form of color, odor, and taste, are insufficient without the bacteriological test to ensure safety from bacteria content capable of causing diarrhea in consumers. The low $\mathrm{pH}$ criterion which ranges between 6.5- 8.6 indicates acidity due to the presence of dissolved metals such as iron [5].

Moreover, refill drinking water is widely utilized by the community because it is easily accessed and affordable as well as the prospect of delivery service. DAMIU are found ranging from big cities to rural areas owing to the low business capital and the clear market share. In addition, it is easy to obtain operational permits, meanwhile, routine supervision and guidance by the health department are also important [6]. According to the legal protection for DAMIU consumers no.8 of the year 1999, consumers have the right to access hygiene information of refill drinking water obtained through regular laboratory tests. However, this has not been carried out properly as reported by a study conducted in a village in Bali [7].

Coronavirus Infection Diseases 19 (COVID-19), is caused by a new virus, known as SARSCoV-2 which reportedly originated from Wuhan, China in December 2019. Therefore, there is a 
need to educate the public on the importance of maintaining personal and environmental hygiene to reduce the spread of the virus by drinking only processed water. Furthermore, the data on the Riau emergency response for COVID-19 from the Riau health department website accessed on March 2, 2021, stated that Kampar Regency including the Koto Kampar Hulu sub-District constitutes one of the areas with high COVID-19 cases with 80 death including health workers [8].

During the COVID-19 pandemic (up to 1 year now), the availability of clean and healthy water for the community was needed to support government programs in preventing the pandemic and general environmental health especially in terms of 3M (use a mask, wash hands using soap with clean water, keep distance). This study aims to examine the characteristics and the bacteriological quality standard of DAMIU raw water in the Koto Kampar Hulu Subdistrict as part of the evaluation for the health department in monitoring and standardizing clean water supply for the community. Also, it provides recommendations on consumer protection to DAMIU entrepreneurs that fail to comply with quality regulations.

\section{METHODS}

This was a descriptive study conducted using a quantitative methods approach laboratory test research to analyze the E. coli and Coliform bacteria content in the water samples used by the 7 depots for refilling drinking water in Koto Kampar Hulu Sub-districts. Bacteriological tests were carried out using the MPN (Most probable number) method, which is the closest estimate of total coliform and E. coli per $100 \mathrm{ml}$ of a water sample. Meanwhile, this method consists of two stages, namely the preliminary (presumptive test) and the confirmation (confirmative test).

The number of the depot(s) for each Sub-district includes Tanjung (1), Tabing(1), Gunung Malelo(2), Sibiruang(1), and Bandur Pick Village(2) respectively. Furthermore, the sample examination was carried out at the Health Laboratory, Kampar Subdistrict Health Office from March to December 2019.

The Informants were individuals who are conversant and directly involved with the research problem. In addition, the respondents were also the owners of the refill drinking water depots used in this study.

Table 1. Research Informant

\begin{tabular}{cccc}
\hline No & Informant & Informant Name & Description \\
\hline 1 & Depot 1 & Informant A & Owner \\
2 & Depot 2 & Informant B & Owner \\
3 & Depot 3 & Informant C & Owner \\
4 & Depot 4 & Informant D & Owner \\
5 & Depot 5 & Informant E & Owner
\end{tabular}


E-ISSN: 2808-5361 http://e-journal.fkmumj.ac.id/
Proceeding The First

Muhammadiyah Internasional-

Public Health and Medicine

Conference

6 Depot $6 \quad$ Informant $\mathrm{F} \quad$ Owner

7 Depot 7 Informant G

Table 2. Definition of Terms

\begin{tabular}{|c|c|c|c|}
\hline No & Variable & Definition & Measuring Instrument \\
\hline 1 & $\begin{array}{l}\text { The Total } \\
\text { Coliform and E } \\
\text { Coli bacteria, }\end{array}$ & $\begin{array}{l}\text { The content of Coliform and E. Coli bacteria in raw } \\
\text { water is based on laboratory results. } \\
\text { Note: The raw water referred to in this research is the } \\
\text { type of water that is later processed into drinking } \\
\text { water from various sources. }\end{array}$ & Laboratory Test \\
\hline
\end{tabular}

Data collection was carried out by taking samples, laboratory examinations, interviews, and observations at the refill drinking water filling point in the study areas. Meanwhile, the data were analyzed descriptively by triangulation, which involves observing the results of the laboratory tests and analyzing interviews as well as check-lists results. Based on the analysis, positive results indicate the presence of Coliform and E. coli while negative contains neither.

The formula for the percentage $(\%)$ of drinking water depot characteristics:

1. Condition of the depot (number of depot characteristics/ total depots) X 100

2. Source of raw water (Total raw water sources / total depots) $\mathrm{x} 100$

3. Distance from raw water sources (Total distance from raw water source / total depots) / $\mathrm{x}$ 100

\section{RESULTS AND DISCUSSIONS}

The DAMIU business is rapidly evolving in Kampar Regency, Riau Province based on the data obtained from the Kampar Subdistrict Health Office from January to December 2018 with a total of 51 working areas of 6 (six) Sub-districts. On average, the DAMIU in these areas uses mountain springs, drilling, and dug wells as raw water sources, meanwhile, all depots open from 08.00 to 19.00 and are directly managed by the owners.

Due to the increasing population density and the difficulties in getting clean water, the growth of the refill drinking water industry in the Koto Kampar Hulu Sub-district continues to increase. Furthermore, the Public Health Center also monitors the lean (raw) water quality every 6 months following the Minister of Health Regulation No. 416/1990. However, the observation was only based on physical conditions such as color, cloudiness, and taste.

The characteristics of DAMIU's operations in Koto Kampar Hulu Subdistrict are generally in line with other businesses (100\%). Besides, the raw water, used for refill drinking water was obtained from 3 sources namely hills (14.2\%), drilling (28.6\%), and dug wells (42.9\%). 
E-ISSN: $2808-5361$ http://e-journal.fkmumj.ac.id/
Proceeding The First Muhammadiyah InternasionalPublic Health and Medicine

Conference

Furthermore, DAMIU distance from the sources includes $\geq 20 \mathrm{~km}(28.5 \%), 20-50 \mathrm{~km}(57.1 \%), \geq 50$ $\mathrm{km}(14.2 \%)$, as shown in Table 3 . The characteristics of the refill drinking water depot are presented below.

Table 3. Characteristics of Refill Drinking Water Depots

\begin{tabular}{|c|c|c|c|}
\hline No & Characteristics of Drinking Water Depots & Total DAMIU & $\%$ \\
\hline \multirow[t]{3}{*}{1} & Depots Condition & & \\
\hline & a. Only drinking water depot. & 0 & $0 \%$ \\
\hline & b. With other activities & & $100 \%$ \\
\hline \multirow[t]{4}{*}{2} & Source of raw water & & \\
\hline & a. Hill (Depot 2) & 1 & $14,2 \%$ \\
\hline & b. Drilling well (Depots $3 \& 4$ ) & 2 & $28,5 \%$ \\
\hline & c. Dug well (Depots $1,5,6 \& 7$ ) & 4 & $57,1 \%$ \\
\hline \multirow[t]{4}{*}{3} & Distance from raw water sources & & \\
\hline & a. $\leq 20 \mathrm{~km}($ Depot $1,3,4 \& 5)$ & 4 & $57,1 \%$ \\
\hline & b. $20-50 \mathrm{~km}$ (Depot 6) & 1 & $14,2 \%$ \\
\hline & c. $\geq 50 \mathrm{~km}($ Depot $2 \& 7)$ & 2 & $28,5 \%$ \\
\hline
\end{tabular}

Table 4 shows the results of E. coli bacteria in raw water (hill, drilling, and dug well) obtained at the Kampar Regency Health Office Laboratory from 7 DAMIU raw water samples. Based on the result, raw water had zero (0) E. coli content hence, fulfills quality standards. Meanwhile, the Minister of Health Regulation No.32 of 2017 recommended 0 per 100 millimeters (ml) E. coli levels in raw water to be processed into drinking.

Table 4. Examination Results of E. coli Bacteria in Raw Water (Hill, Drilling, and Dug Well)

\begin{tabular}{cccccc}
\hline No & Depot & Parameter & Result & Description & Source of Raw Water \\
\hline 1 & Depot 1 & E. Coli & 0 & Qualified & Dug well \\
2 & Depot 2 & E. Coli & 0 & Qualified & Hills \\
3 & Depot 3 & E. Coli & 0 & Qualified & Drilling well \\
4 & Depot 4 & E. Coli & 0 & Qualified & Drilling well \\
5 & Depot 5 & E. Coli & 0 & Qualified & Dug well \\
6 & Depot 6 & E. Coli & 0 & Qualified & Dug well \\
7 & Depot 7 & E. Coli & 0 & Qualified & Dug well \\
\hline
\end{tabular}

Based on the biological/bacteriological quality standards stated in the Minister of Health Regulation No.32 of 2017, E. Coli TLV (Threshold Limit Value) of raw water is 0 MPN (Most Probable Number) with the unit in amount $/ 100 \mathrm{ml}$.

Based on Table 5, 4 DAMIU sources showed positive results for coliform, namely DAMIU 1 (350), 2 (350), 4 (350), and 7 (350) with higher values compared to TLV 50/100 ml. Meanwhile, raw water from DAMIU 3, 5, 6 was free from coliform bacteria and fulfills quality standards.

\section{Table 5. Examination Results of Coliform Bacteria in Raw Water}




\begin{tabular}{cccccc}
\hline No & Depot & Parameter & Result & TLV & Description \\
\hline 1 & Depot 1 & Coliform & 350 & 50 & Unqualified \\
2 & Depot 2 & Coliform & 350 & 50 & Unqualified \\
3 & Depot 3 & Coliform & 13 & 50 & Qualified \\
4 & Depot 4 & Coliform & 350 & 50 & Unqualified \\
5 & Depot 5 & Coliform & 8 & 50 & Qualified \\
6 & Depot 6 & Coliform & 13 & 50 & Qualified \\
7 & Depot 7 & Coliform & 350 & 50 & Unqualified \\
\hline
\end{tabular}

Coliform TLV (Threshold Limit Value) based on the biological/bacteriological quality standards by the Minister of Health Regulation No.32 of 2017 is 50 MPN (Most Probable Number) with units in Amount/100 ml.

Based on the results, all raw water for refill drinking water in Koto Kampar Hulu Subdistrict fulfilled quality standards for E. coli bacteria $(0 / 100 \mathrm{ml})$, however, 4 DAMIU had coliform bacteria above the threshold limit value $(\mathrm{TLV}=50)$. This is due to the absence of raw water certification for all DAMIU which ought to be a requirement for operational licensing of depots. Based on the Minister of Health Regulation No.736 of 2010 on the quality control of drinking water, the TLV of total coliform bacteria in raw water to be processed into drinking water is 50/100 $\mathrm{ml}$. The inability to fulfill the physical, chemical, and bacteriological requirements are often caused by the proximity of raw water sources to sewers and storage that are not in line with the standard regulation.

The presence of coliform bacteria in refill drinking water is caused by the unclean condition of the depot (dirty walls and floors as well as stagnant water) or low sanitation of DAMIU and failure of depot employees to wash hands before working. In addition, the use of UV light which is turned on when the water is dispensed into the gallon reduces the effectiveness of UV rays in killing germs. A study in Banyuwangi reported that DAMIU Hygiene was generally good (up to 93\%) but still needs supervision and guidance by the local health officers [10].

Another study in Delima Village, Pekanbaru city showed positive E. Coli content and negative Total Coliform in drinking water samples [11]. Furthermore, a survey on drinking water quality in the Tabanan-Bali area reported that the bacteriological parameters of the water samples fulfilled applicable requirements [12]. The bacteriological quality test of 24 DAMIU in Blora City was negative and only 1 depot showed positive coliform results [13]. Meanwhile, the DAMIU exam. ination in Parigi Sub-district, Parigi Muotong Regency, Central Sulawesi Province showed that 9 were positive for coliform bacteria in raw water while 13 were positive for the bacteria in processed drinking water [14]. These results indicate that the quality of raw water is better 
compared to processed water resulting from the unhygienic or poor maintenance of the DAMIU equipment's hence, the amount of contaminated water was greater. Therefore, 4 DAMIU need to be evaluated and supervised by the health office to prevent disease outbreaks as the DAMIU drinking water is mainly consumed by individuals prone to diarrhea (toddlers and elderly).

Nowadays, DAMIU offers the best services by providing home delivery services as well as refill gallons, hence customers are not required to provide personal gallons and only pay for refill water. Moreover, DAMIU entrepreneurs in Koto Kampar Hulu Sub-district generally have an operational vehicle namely $1 \mathrm{car}$ and a motorbike to distribute products. The availability of transportation is a good marketing strategy for drinking water businesses [9].

DAMIU 4 and 5 market products by transporting it with a 1000-liter tank truck, where the water is piped through the tank faucet to the consumer's gallon. Furthermore, the depot owner is in charge of marketing the products and daily delivery to prospective customers. Service coverage is limited to the working area (surrounding housing) with a business length between 5 to 10 years. In addition, all depots have no workers, hence the owner takes sole responsibility for the business. The building area is between $10 \mathrm{~m}^{2}$ to $50 \mathrm{~m}^{2}$, with different conditions. Aside from the refill drinking water business, the depot owner also has other businesses such as LPG gas which is placed in one room with refill drinking water.

Products from water depots obtained from three sources namely dug wells, hill, and drilling wells showed positive results for coliform bacteria. Meanwhile, $85 \%$ of the DAMIU raw water originated from drilling and dug wells. Most of the unprocessed/unfiltered raw water originating from wells contains Total Coliform and E. Coli bacteria [15]. A study on well water containing high lime content in the Gedangsari Sub-district of Yogyakarta had no calcification effect or kidney stones formation on the consumers [16].

These bacteria are spread from human to human by flies, through dirty hands, food contaminated with feces, uncovered food, and unsanitized environments [17]. According to [18] uncovered DAMIU raw water reservoir is a potential source for the Aedes aegypti mosquito larvae.

The drinking water quality index of DAMIU at Makassar city was included in the medium criteria because the value was at $60 \%$. A low $\mathrm{pH}$ value (4-5) causes water to be slightly acidic and taste bitter [19]. Therefore, further processing is required following quality standards and guidelines together with thorough supervision by the local health officers. Iran has the same problem with water pollution and has investigated permissible limits of the World Health Organization drinking water quality guidelines [20]. 
The government is urged to further improve environmental health and foster clean and healthy behavior (PHBS) program during the COVID-19 pandemic. The 5M health protocol (wearing masks, washing hands with soap, maintaining distance, avoiding hassles, and reducing mobilization), especially in the aspect of maintaining distance is difficult to apply in the Indonesian culture, where family ties are very strong. It was reported that close friendships/relationships without paying attention to environmental health increased hepatitis virus transmission [21]. In addition, new clusters are created such as in the case of Islamic boarding school students that became the new cluster of infections and had to be quarantined to prevent further transmission.

A study in 2018 reported that the availability of clean water is required to support the handwashing with soap (CPTS) program to prevent hepatitis disease [22]. This is part of the Community-Based Total Sanitation (STBM) and 3M program in preventing the spread of the COVID-19 virus. Furthermore, this is carried out by educating the community on personal hygiene including the elderly which are more vulnerable to the deadly virus [23].

Based on Permenkes (Minister of Health Regulation) no. 492 of 2010, drinking water consumed by the community is required to fulfill quality standard criteria. The regional health offices are responsible for supervision [24], while DAMIU producers are responsible for drinking water that failed to meet the criteria[25]. These are carried out with the presumption principle, that internal and external supervision is performed by the health office. The implementation of this regulation has been evaluated in Denpasar City [26]. Currently, DAMIU growth is increasing from rural to urban areas, however, this is not balanced to the quality of drinking water as observed in the Koto Kampar Hulu sub-district which still contains bacteria in its raw water. According to researched [27] some DAMIUs in Semarang City have no certificate of proper sanitation. Therefore, public awareness is needed to identify DAMIU with a sanitation certificate to improve the quality of drinking water to prevent disease.

Legal protection for DAMIU consumers has been stipulated in government regulations such as the Indonesian Minister of Health Regulation No. 736 of 2010 concerning the quality control of drinking water [28]. It was stated that the quality control of drinking water is to be performed once a month to examine physical and microbiological parameters, and once every six (6) months for additional chemical parameters. Consumers are to only purchase drinking water from DAMIU that has received permission from the health office in form of a sanitation certificate. Furthermore, the application of quality standards for drinking water sold with domestic food and beverages in Slawi Regency, especially Tegal district, still needs to be improved [29] Similarly, the local health office 
E-ISSN: 2808-5361 http://e-journal.fkmumj.ac.id/
Proceeding The First Muhammadiyah InternasionalPublic Health and Medicine

Conference

in Pontianak failed to carry out periodic checks [30]. In Malaysia, legal protection for consumers has been implemented to maintain health quality and preserve environmental resources [31].

The legal protection for consumers is stipulated in the Minister of Public Works Regulation No. 13 / PRT / M / 2013 concerning the National policy and strategy for the development of a drinking water supply system. This policy states that the government is responsible for providing facilities and infrastructure for clean water in cooperation with the local community, starting from planning, development, and operations until it becomes Village-Owned Enterprises (BUMD). These activities usually continue with monitoring the quality standards and maintaining the construction of the drinking water supply system. Besides, this program aims to increase the knowledge and development of rural communities especially in the aspect of the clean and healthy behavior (PHBS) program [32].

PAMSIMAS (Community Based Water Supply and Sanitation Program) is a National drinking water management program that aims to assist rural communities to independently find clean water sources by planning the facility construction to be publicly accessible to the entire community. This program needs to be socialized and initiated by the community to create a sense of responsibility in the operational management of facilities and infrastructure in the provision of clean raw water from and for the community [33]. Furthermore, there is a need to prioritize the development of drinking water facilities due to the increasing population growth. In Bajo Village, the fulfillment of clean water was $50 \%$ hence, it is necessary to add new drinking water sources as well as raw water storage areas for reserves. Moreover, there is a needs to also provide a drinking water faucet to maintain the quality standard. In the long term, the community needs to be independent in managing the need for clean water by forming non-governmental organizations and working with the government through the PAMSIMAS program [34]. Meanwhile, a water distribution system is being developed in the Muara Enim region on a larger scale with a capacity of up to 20 years as the existing services only cater for $50 \%$. Hence, it is necessary to replace and also add new distribution pipes with funds amounting to 3 billion rupiahs [35].

The evaluation of the Community Based Water Supply and Sanitation Program (PAMSIMAS) supported by the World Bank in one of Bluto District, Sumenep Regency, East Java showed distinctive results with a community participation rate of $95 \%$ coupled with improved water source benefits [36]. This program is to be continued by providing MCK (Bathing, Washing, Toilet) to support Clean and Healthy Behavior (CHB) program pillars 1- 3 which include (BABS) providing toilets to reduce Open Defecation, (CTPS) Washing Hands Using Soap, and PAM - RT 
(Provision of Drinking Water and Food - Household) [37]. Educating the rural community on the need for raw water is important. Consequently, the community recognizes water as a natural resource that needs to be purely maintained to meet immediate and economic needs [38]. The Sikumbang water source, located in Kampar Regency, is a clear and cool natural source from springs, used for daily community needs, and is even traded to Pekanbaru City and Siak Regency in Riau Province.

DAMIU uses Ozonation and UV technology, in research conducted to compare these systems, the results indicated respective advantages and disadvantages in eliminating bacteria in raw water. Based on the evaluation results obtained in the Kebumen Regency, Central Java Province, [39] it was found that $75 \%$ of DAMIU devices was in a good shape indicating that there is still a need for improved maintenance in form of changing microfilter regularly, [40] storing raw water properly, and sterilizing the area to fill drinking water.

Treatment technology plays an important role in providing drinking water that meets the requirements because access to clean and healthy water is a basic right of society. For areas that lack consumable water sources and depend on DAMIU, it is necessary to provide technological innovations to process the raw water and make it suitable for drinking. One of the technologies developed by the central BPPT (Agency for the Assessment and Application of Technology) in processing brackish/salty water to be consumed by communities around the coast which are widely spread throughout Indonesia is the Reverse Osmosa Technology, which is a cheap technology, therefore, it solves the problem of always relying on rainwater or buy at a high price [41]. In Gresik have study to improve water quality from lake to consumption by a community using Fixed Bed Filter Adoption, this study can adoption to other area have same water source [42].

This clean water technology was developed for areas with cloudy and non-sterile raw water sources in a high school in Probolinggo, East Java. It involves a filtration and osmosis system hence, water becomes clearer and ready-to-drink water [43]. The drinking water data collection system was developed online and tested in the Semarang City Health Office. This program is designed to help DAMIU entrepreneurs apply for a health-worthy certificate, laboratory test, and other data integration concerning licensing and status of sanitation [44].

\section{CONCLUSIONS AND SUGGESTIONS}

The characteristics of Refill Drinking Water Depot (DAMIU) operations in Koto Kampar Hulu Subdistrict, Kampar Regency, Riau Province is generally in line with other businesses. 
Besides, the largest raw water source (85\%) is dug and drilling wells while the distance from the water sources is $<20 \mathrm{~km}$. Bacteriological quality standards of DAMIU raw water were in line with the Minister of Health Regulation No.32 of 2017. The results for E. Coli bacteria indicate that all DAMIU fulfill the quality standards $(\mathrm{TLV}=0)$ while 4 DAMIU sources failed to meet the quality standards for Total Coliform Bacteria (TLV 50).

Clean water management during the Covid 19 period is important due to its relation to disease prevention program, the government's Clean and Healthy Behavior (CHB) program, as well as Community-Led Total Sanitation (CLTS) aimed at increasing the availability of clean water that meets standard requirements. Furthermore, supervision and guidance from the Health Officers are needed while DAMIU entrepreneurs are required to standardize the quality of drinking water being sold to fulfill consumers' legal protection in line with the Minister of Health Regulation no. 736 of 2020.

The Community Based Water Supply and Sanitation Program (PAMSIMAS) needs to be implemented in rural areas, especially in areas with limited drinking water sources, to empower communities to independently obtain clean water. In the future, the application of clean water technology is also expected to be incorporated with government, private, and university research institutions to evaluate the quality of drinking water sources at low cost and to ensure the availability of clean water in the community to maintain environmental sanitation and health

\section{THANKYOU-NOTE}

The author is grateful to several parties who provided data support, especially the Public Health Center Koto Kampar Hulu District, Kampar Regency, Riau Province, and to the Masters in Public Health Sciences at the Hang Tuah Pekanbaru College of Health who provided grants for the smooth running of this research.

\section{REFERENCES}

[1] N. 32. Permenkes RI, Standar Baku Mutu Kesehatan Lingkungan Dan Persyaratan Kesehatan Air Untuk Keperluan Higiene Sanitasi, Kolam Renang, Solus Per Aqua, Dan Pemandian Umum. 2017.

[2] A. W. Pratiwi, "Kualitas Bakteriologis Air Minum Isi Ulang di Wilayah Kota Bogor," Kesmas Natl. Public Heal. J., vol. 2, no. 2, p. 58, Oct. 2007, doi: 10.21109/kesmas.v2i2.271. 
[3] R. S. Pakpahan, I. Picauly, and I. N. W. Mahayasa, "Cemaran Mikroba Escherichia coli dan Total Bakteri Koliform pada Air Minum Isi Ulang,” Kesmas J. Kesehat. Masy. Nas. (National Public Heal. Journal); Vol. 9 No. 4 Mei 2015, 2015, doi: 10.21109/kesmas.v9i4.733.

[4] Sudarto, S. F. Retnawaty, Y. Fitri, and A. Suroso, "Uji pH Dan Fisik Air Minum Isi Ulang Di Kecamatan Tapung Kabupaten Kampar,” Phot. J. Sain dan Kesehat., vol. 5, no. 2, pp. 63-70, May 2015, doi: 10.37859/jp.v5i2.587.

[5] D. Abdilanov, W. Hasan, and I. Marsaulina, "Pelaksanaan Penyelenggaraan Hygiene Sanitasi dan Pemeriksaan Kualitas Air Minum pada Depot Air Minum Isi Ulang di Kota Padang Tahun 2012," Lingkung. dan Keselam. Kerja, vol. 2, no. 3, 2013, [Online]. Available: https://www.neliti.com/id/publications/14409/pelaksanaan-penyelenggaraanhygiene-sanitasi-dan-pemeriksaan-kualitas-air-minum\#cite.

[6] I. M. P. Sedana and I. W. B. S. Layang, "Perlindungan Hukum Bagi Konsumen Air Minum Isi Ulang Ditinjau Dari Undang-Undang Nomor 8 Tahun 1999 Tentang Perlindungan Konsumen (Studi kasus: Desa Peliatan, Kecamatan Ubud), Kertha Semaya J. Ilmu Hukum; Vol 4 No 2, Oct. 2018, [Online]. Available: https://ojs.unud.ac.id/index.php/kerthasemaya/article/view/44310.

[7] D. K. Riau, "Update Covid 19 Propinsi Riau," https://corona.riau.go.id/, 2021. .

[8] S. Yudo and A. I. Sitomurni, "Implementasi Teknologi Pengolahan Air Siap Minum Dan Pengembangan Usaha Galon Air Siap Minum Studi Kasus: Penerapan Teknologi Pengolahan Air Siap Minum Di SMK Al-Kahfi, Sumbawa,” J. Rekayasa Lingkung., vol. 11, no. 2, Mar. 2019, doi: 10.29122/jrl.v11i2.3439.

[9] W. Mila, S. L. Nabilah, and S. I. Puspikawati, "Higiene dan Sanitasi Depot Air Minum Isi Ulang di Kecamatan Banyuwangi Kabupaten Banyuwangi Jawa Timur : Kajian Deskriptif," IKESMA, vol. 16, no. 1, p. 7, Jun. 2020, doi: 10.19184/ikesma.v16i1.14841.

[10] S. M. Chaniggia, P. Febriana, and W. Syafitri, "Pemeriksaan Most Probable Number (Mpn) Coliform Dan Colifecal Pada Air Minum Isi Ulang Dari Depot Air Minum Isi Ulang Di Kelurahan Delima Kota Pekanbaru,” Klin. Sains J. Anal. Kesehat., vol. 8, no. 2, pp. 90-97, 2020, doi: 10.36341/klinikal_sains.v8i2.1399.

[11] I. M. Sudiana and I. G. Sudirgayasa, "Analisis Cemaran Bakteri Coliform Dan Eschericia Coli Pada Depot Air Minum Isi Ulang ( DAMIU ),” J. Kesehat. Bakti Tunas Husada J. Ilmu Keperawatan, Anal. Kesehat. dan Farm., vol. 20, no. 1, pp. 52-61, 2020. 
[12] L. A. Natalia, S. Harninabintari, and D. Mustikaningtyas, "Kajian Kualitas Bakteriologis Air Minum Isi Ulang Di Kabupaten Blora,” Unnes J. Life Sci., vol. 3, no. 1, pp. 31-38, 2014.

[13] Jumriah, A. H. Laenggeng, and Budiman, "Uji Kandungan bakteri Koliform pada AMI di DAMIU,” pp. 452-464, 2016, doi: http://dx.doi.org/10.31934/jom.v1i1.378.

[14] G. V. Souisa and L. M. Y. Janwarin, “Kualitas Sumur Gali di Dusun Wahakaim,” HIGEIA (Journal Public Heal. Res. Dev., vol. 2, no. 4, pp. 612-621, Oct. 2018, doi: 10.15294/higeia.v2i4.23632.

[15] S. Sulistyawati, F. D. Astuti, R. Trisasri, and A. Rustiawan, "Well Water Consumed and Urolithiasis in Gedangsari Subdistrict, Yogyakarta," Kesmas Natl. Public Heal. J., vol. 11, no. 1, p. 26, Aug. 2016, doi: 10.21109/kesmas.v11i1.1165.

[16] D. Susanna, Y. M. Indrawani, and Z. Zakianis, "Kontaminasi Bakteri Escherichia coli pada Makanan Pedagang Kaki Lima di Sepanjang Jalan Margonda Depok, Jawa Barat,” Kesmas Natl. Public Heal. J., vol. 5, no. 3, pp. 110-115, 2010, [Online]. Available: http://journal.fkm.ui.ac.id/kesmas/article/view/143.

[17] M. J. T. Pawenang, "Karakteristik Sumur Gali dengan Keberadaan Jentik Nyamuk Aedes aegypti,” HIGEIA (Journal Public Heal. Res. Dev., vol. 1, no. 1, pp. 8-14, 2017.

[18] S. S. Sakkangi and M. N. Z. Leo, "Indeks Kualitas Air Minum Pada Depot Isi Ulang Di Parang Tambung, Kota Makassar,” J. Environ. Sci., vol. 2, no. 1, Oct. 2019, doi: 10.35580/jes.v2i1.11426.

[19] I. Sumarni and D. Susanna, "Kondisi Kesehatan Lingkungan Pesantren dan Perilaku Hidup Bersih dan Sehat Siswa dengan Kejadian Hepatitis,” Kesmas Natl. Public Heal. J., vol. 9, no. 2, p. 179, Dec. 2014, doi: 10.21109/kesmas.v9i2.515.

[20] M. M. Heydari, A. Abbasi, S. M. Rohani, and S. M. A. Hosseini, "Correlation study and regression analysis of drinking water quality in Kashan City, Iran," Walailak J. Sci. Technol., vol. 10, no. 3, pp. 315-324, 2013, DOI: 10.2004/wjst.v10i3.338.

[21] P. S. H, K. Azhar, J. Pradono, and N. E. W. Sukoco, "Hubungan Perilaku Cuci Tangan, Pengelolaan Air Minum Dan Rumah Sehat Dengan Kejadian Hepatitis Di Indonesia,” J. Ekol. Kesehat., vol. 17, no. 1, pp. 41-51, 2018, doi: 10.22435/jek.17.1.139.41-51.

[22] H. Herniwanti, O. Dewi, J. Yunita, and E. P. Rahayu, "Penyuluhan Perilaku Hidup Sehat Dan Bersih (PHBS) dan Gerakan Masyarakat Hidup Sehat (GERMAS) kepada Lanjut Usia 
Volume I Tahun 2021

November 2021
E-ISSN: 2808-5361 http://e-journal.fkmumj.ac.id/
Proceeding The First Muhammadiyah InternasionalPublic Health and Medicine

Conference

(LANSIA) Menghadapi Masa Pandemi Covid 19 dan New Normal dengan Metode 3M," J. Abdidas, vol. 1, no. 5 SE-, pp. 363-372, Sep. 2020, doi: 10.31004/abdidas.v1i5.82.

[23] H. Herniwanti, J. Yunita, E. P. Rahayu, and K. Kiswanto, "Penyuluhan Personal Higyene pada Lanjut Usia di UPT Pelayanan Sosial Tresna Werdha Husnul Khotimah Kota Pekanbaru," J. Abdidas, vol. 1, no. 4 SE-, pp. 254-260, Aug. 2020, doi: 10.31004/abdidas.v1i4.55.

[24] 2010 Permenkes RI No.492, "Peraturan Menteri Kesehatan Republik Indonesia Nomor 492/Menkes/Per/IV/2010 Tentang Persyaratan Kualitas Air Minum,” Kemenkes RI. 2010.

[25] M. P. Anggreni and I. N. Suyatna, "Tanggung Jawab Produsen Air Minum Isi Ulang Yang Terbukti Tidak Memenuhi Persyaratan Permenkes Nomor 492/Menkes/Per/Iv/2010.," Kertha Semaya J. Ilmu Hukum; Vol. 02, No. 01, Februari 2014, Mar. 2018, [Online]. Available: https://ojs.unud.ac.id/index.php/kerthasemaya/article/view/38417.

[26] K. S. Brahmatantri and A. A. G. Oka Parwata, "Implementasi Keputusan Menteri Kesehatan Nomor 492/Menkes/Per/Iv/2010 Tentang Persyaratan Kualitas Air Minum Di Kota Denpasar,” Kertha Semaya J. Ilmu Hukum; Vol. 01, No. 11, Novemb. 2013, vol. 01, no. $11, \quad$ Mar. 2018, [Online]. Available: https://ojs.unud.ac.id/index.php/kerthasemaya/article/view/38248.

[27] A. Kurniawan, "Perancangan Iklan Layanan Masyarakat Tentang Pentingnya Higiene Sanitasi Bagi Depot Air Minum Isi Ulang Di Kota Semarang,” Dokumen Karya Ilmiah | Skripsi | Prodi Desain Komunikasi Visual - S1 | FIK | UDINUS |, 2017.

[28] 2010 Permenkes RI No.736, Tentang Pengawasan Kualitas Air Minum. 2010.

[29] A. Aziz, P. Prananingtyas, and I. Irawati, "Perlindungan Hukum Terhadap Konsumen Air Minum Isi Ulang Oleh Dinas Kesehatan Di Kabupaten Slawi.,” J. Pembang. Huk. Indones., vol. 1, no. 2, pp. 213-225, May 2019, doi: 10.14710/jphi.v1i2.213-225.

[30] V. L. Sidauruk, “Tanggung Jawab Dinas Kesehatan Terhadap Kualitas Air Minum Pada Usaha Depot Air Minum Isi Ulang Di Kecamatan Pontianak Barat,” Universitas Tanjung Pura Pontianak, 2015.

[31] M. R. Razman et al., "Consumer protection and environmental sustainability on drinking bottled water from Malaysian sale of goods law perspectives: Focusing on statutory implied terms,” Res. J. Appl. Sci., 2012, DOI: 10.3923/rjasci.2012.36.40. 
E-ISSN: 2808-5361 http://e-journal.fkmumj.ac.id/
Proceeding The First Muhammadiyah InternasionalPublic Health and Medicine

Conference

[32] F. Afrilya and A. Rahmawati, "Program Penyediaan Air Minum Berbasis Masyarakat di Desa Tiris Kecamatan Tiris Kabupaten Probolinggo ( Water Supply Based On Community Programme at Tiris Village Tiris Sub-District Probolinggo District ),” 2014.

[33] Saparuddin, "Rintisan menuju kemandirian air minum masyarakat desa di sulawesi tengah," SMARTek, vol. 3, no. 3, pp. 199-208, 2005.

[34] et all Ferdi Than, "Studi Pengembangan Kebutuhan Air Minum Di Permukiman Desa Bajo Kecamatan Sanana Utara Kabupaten Kepulauan Sula,” J. SPASIAL, vol. 4, no. 1, 2018.

[35] A. Alatas, "Perencanaan Pengembangan Sistem Distribusi Air Minum di Kecamatan Muara Enim Kabupaten Muara Enimprovinsi Sumatera Selatan,” vol. 5, no. 2, pp. 1-12, 2017.

[36] L. Hasanah, "Partipasi Masyarakat Dalam Keberlanjutan Program (Pamsimas) Penyediaan Air Bersih Dan Sanitasi Berbasis Masyarakat Di Desa Aeng Dake Kecamatan Bluto Tahun 2019," Bul. Keslingmas, vol. 38, no. 1, pp. 119-123, Mar. 2019, doi: 10.31983/keslingmas.v38i1.4083.

[37] H. Herniwanti, O. Dewi, N. Rani, J. Yunita, E. P. Rahayu, and B. Hartono, "Penyuluhan Sanitasi Total Berbasis Masyarakat (STBM) sebagai Support Program Kesehatan Lingkungan pada Masa Pandemi COVID-19," J. Abdidas, vol. 2, no. 2, pp. 435-441, 2021.

[38] S. Subekti, "Studi Identifikasi Kebutuhan Dan Potensi Air Baku Air Minum Kabupaten Pasuruan,” J. Momentum UNWAHAS, vol. 8, no. 2, p. 114808, 2012.

[39] D. R. Sofia, "Perbandingan Hasil Disinfeksi Menggunakan Ozon Dan Sinar Ultra Violet Terhadap Kandungan Mikroorganisme Pada Air Minum Isi Ulang. Agroscience," AGROSCIENCE (AGSCI), vol. 9, no. 1, p. 82, Jun. 2019, doi: 10.35194/agsci.v9i1.636.

[40] Y. Driyaningsih, S. Abdullah, and S. Suparmin, "Hubungan Kegiatan Pengoperasian Dan Pemeliharaan Alat Pengolahan Air Terhadap Kualitas Mikrobiologi Air Minum Pada Depot Air Minum (Dam) Di Kabupaten Kebumen Tahun 2016,” Bul. Keslingmas, vol. 36, no. 1, pp. 65-69, Mar. 2017, doi: 10.31983/keslingmas.v36i1.3009.

[41] W. Widayat, "Inovasi Teknologi Air Minum Berbasis Masyarakat,” J. Air Indones., vol. 10, no. 2, Sep. 2019, doi: 10.29122/jai.v10i2.3762.

[42] E. KUSDARINI, L. HAKIM, B. YANUWIADI, and S. SUYADI, "Study in the Development of Fixed Bed Filter Adoption of Public Health of Lake Water Users," Walailak J. Sci. Technol., vol. 18, no. 8, 2021, DOI: 10.48048/wjst.2021.9131. 
E-ISSN: 2808-5361 http://e-journal.fkmumj.ac.id/
Proceeding The First Muhammadiyah InternasionalPublic Health and Medicine Conference

[43] R. H. Indriatmoko and I. Setiadi, "Analisis Terhadap Kualitas Air Baku Sebagai Dasar Perencanaan Sistem Pengolahan Air Siap Minum Untuk Masyarakat.,” J. Air Indones., vol. 11, no. 1, Jan. 2020, doi: 10.29122/jai.v11i1.3934.

[44] et all Artanto, "Sistem Pendataan Depot Air Minum Isi Ulang Berbasis Web," Transm. Vol 13, No 4 Transm. - 10.12777/transmisi.13.4.121-126, [Online]. Available: https://ejournal.undip.ac.id/index.php/transmisi/article/view/3653. 